Journal of Jazz Studies vol. 8, no. 1, pp. 105-113 (Spring 2012)

\title{
Jazz Research Bibliography (2009-2010)
}

\author{
Robin Desmeules
}

In this bibliography you will find scholarly articles about jazz music from journals not specifically dedicated to the study of jazz that were published in 2009 and 2010. This is the most recent installment of a project begun by Keith Waters and Jason R. Titus, who compiled the first three bibliographies for volumes 11 (1999-2000), 12 (2001-2002), and 13 (2003-2004) of the Annual Review of Jazz Studies. James McGowan and I compiled the next two installments, which were published in volumes 7.1 (2005-2006) and 7.2 (2007-2008) of this journal. Some recently discovered articles published before 2009 also appear.

This current installment continues the tradition of including articles that address a broad range of topics from virtually any area of study as long as it includes significant content relevant to the primary focus of this bibliography. This installment therefore includes articles dealing with jazz history, music theory, cultural studies, music cognition, ethnomusicology, computer programming, and much more. As with earlier installments, reviews, work without original research or interpretation, and articles that address other "jazz" art forms, such as literature, poetry, or dance, are not included in this bibliography. When an article is available online for free, the URL has been provided. For articles written in other languages, the title is listed in both the original language and in translation where possible. The language of all nonEnglish articles is also listed.

For future installments I welcome recommendations of any academic articles that appear in non-jazz journals after 2010, as well as those published between 1999 and 2010 that were not included in this or previous installments of the bibliography. Please email complete citations of articles to Robin Desmeules (rdesmeules@gmail.com).

Arvidsson, Alf. "Mike Disc-Courses on Hot Jazz: Discursive Strategies in the Writings of Spike Hughes (1931-33).” Popular Music History 4/3 (December 2009): 251-269.

\footnotetext{
copyright by author $\subseteq \bigoplus \bigoplus \begin{aligned} & \text { Except where otherwise noted, this work is licensed under } \\ & \text { http://creativecommons.org/licenses/by-nc-nd/3.0 }\end{aligned}$
} 
Asukile, Thabiti. "J.A. Rogers' Jazz at Home: Afro-American Jazz in Paris during the Jazz Age.” Black Scholar 40/3 (Fall 2010): 23-35.

Atzmon, Gilad. "Primacy of the Ear." Index on Censorship 39/3 (Sep 2010): 67-77.

Baraka, Amiri and Pawel Jedrzejko. "Still a Revolutionary ..." New Theatre Quarterly 26/104 (November 2010): 340-350.

Barber, Simon. "Smooth Jazz: A Case Study in the Relationships Between Commercial Radio Formats, Audience Research and Music Production.” Radio Journal: International Studies in Broadcast E Audio Media 8/1(Oct 2010): 51-70.

Barzel, Tamar. “An Interrogation of Language: 'Radical Jewish Culture' on New York City's Downtown Music Scene.” Journal of the Society for American Music 4/2 (May 2010): 215-250.

Benadon, Fernando. “Gridless Beats.” Perspectives of New Music 47/1 (Winter 2009): 135-164.

Benadon, Fernando. "Time Warps in Early Jazz." Music Theory Spectrum 31/1 (Spring 2009): 1-25.

Bennet, Robert. "Songs of Freedom: The Politics and Geopolitics of Modern Jazz." Mosaic - A Journal for the Interdisciplinary Study of Literature 42/1 (Mar 2009): 51-66.

Birtwistle, Andy. "Marking Time and Sounding Difference: Brubeck, Temporality and Modernity." Popular Music 29/3 (Oct 2010): 251-71.

Borém, Fausto and Maurício Freire Garcia. "Cannon de Hermeto Pascoal: Aspectos musicais e religiosos em uma obra-prima para flauta / Cannon by Hermeto Pascoal: Musical and Religious Aspects in a Flute Masterpiece." [Article written in Portuguese.] Per musi: Revista acadêmica de música 22 (Jul-Dec 2010): 63-79.

Burland, Karen and Stephanie E Pitts. "Understanding Jazz Audiences: Listening and Learning at the Edinburgh Jazz and Blues Festival.” Journal of Nerw Music Research 39/2 (2010): 125-134.

Butterfield, Matthew. "Participatory Discrepancies and the Perception of Beats in Jazz.” Music Perception 27/3 (Feb 2010): 157-175.

Butterfield, Matthew W. "Variant Timekeeping Patterns and Their Effects in Jazz Drumming.” Music Theory Online 16/4 (Dec 2010). http://www.mtosmt.org/issues/mto.10.16.4/mto.10.16.4.butterfield.html

Carvalho, John M. "Repetition and Self-Realization in Jazz Improvisation." Journal of Aesthetics and Art Criticism 68/3 (2010): 285-290. 
Caudwell, Jayne. “The Jazz-Sport Analogue: Passing Notes on Gender and Sexuality.” International Review for the Sociology of Sport 45/2 (June 2010): 240-248.

Černyšov, Aleksandr Valer'evič (Чернышов, Александр Валерьевич). “Опус-джаз / Opus-jazz.” [Article written in Russian.] Muzykovedenie 4 (2009): 8-18.

Ciorba, Charles R. "Predicting Jazz Improvisation Achievement Through the Creation of a Path-Analytical Model." Bulletin of the Council for Research in Music Education 180 (Spring 2009): 43-57.

Clark, John L. Jr. "Archie Bleyer and the Lost Influence of Stock Arrangements in Jazz.” American Music 27/2 (Summer 2009): 138-179.

Costa-Lima Neto, Luiz. "O cantor Hermeto Pascoal: Os instrumentos da voz / The Singer Hermeto Pascoal: The Instruments of the Voice." [Article written in Portuguese.] Per musi: Revista acadêmica de música 22 (Jul - Dec 2010): 44-62.

Crist, Stephen A. "Jazz as Democracy? Dave Brubeck and Cold War Politics." Journal of Musciology 26/2 (Spring 2009): 133-174.

Curtis, Rebecca Anne. "Australia's Capital of Jazz? The (Re)creation of Place, Music and Community at the Wangaratta Jazz Festival." Australian Geographer 41/1 (2010): 101-116.

Davison, P. Dru. "The Role of Self-Efficacy and Modeling in Improvisation Among Intermediate Instrumental Music Students." Journal of Band Research 45/2 (Spring 2010): 42-58.

Dean, Roger and Freya Bailes. "The Control of Acoustic Intensity during Jazz and Free Improvisation Performance." Critical Studies in Improvisation / Études critiques en improvisation 6/2 (Dec 2010).

http://www.criticalimprov.com/article/view/1193

Dempsey, Nicholas P. "Stimulated Recall Interviews in Ethnography." Qualitative Sociology 33/3 (Sep 2010): 349-367.

Dennen, James. “On Reception of Improvised Music.” TDR - The Drama Review- $A$ Journal of Performance Studies 53/4 (Winter 2009): 137-150.

Dobson, Melissa C. "Performing Your Self? Autonomy and Self-Expression in the Work of Jazz Musicians and Classical String Players." Music Performance Research 3 (Jun 2010): 42-60.

Doffman, Mark. "Making it Groove! Entrainment, Participation and Discrepancy in the 'Conversation' of a Jazz Trio.” Language \& History 52/1 (May 2009): 130147. 
Duranti, Alessandro. "L'oralité avec impertinence: Ambivalence par rapport à l'écrit chez les orateurs samoans et les musiciens de jazz américains / Orality with Attitude: Ambivalent Views of Literacy Among Samoan Speechmakers and Jazz Musicians." [Article written in French.] L'Homme 189/1 (2009): 23-47.

Fabiani, Jean-Louis. "Live at the village Vanguard. Le paradoxe de l'écoute enregistrée du jazz / Live at the Village Vanguard: The Paradox of Listening to Recorded Jazz." [Article written in French.] L'Année sociologique 60/2 (2010): 387-402.

Fischlin, Daniel. “See Clearly ... Feel Deeply': Improvisation and Transformation: John McLaughlin Interviewed by Daniel Fischlin." Critical Studies in Improvisation / Études critiques en improvisation 6/2 (Dec 2010). http://www.criticalimprov.com/article/view/1332/1929

Fornaes, Johan. "Exclusion, Polarization, Hybridization, Assimilation: Otherness and Modernity in the Swedish Jazz Age." Popular Music and Society 33/2 (2010): 219236.

Fosler-Lussier, Danielle. "Cultural Diplomacy as Cultural Globalization: The University of Michigan Jazz Band in Latin America." Journal of the Society for American Music 4/1 (Feb 2010): 59-93.

Gillett, Rachel. "Jazz and the Evolution of Black American Cosmopolitanism in Interwar Paris." Journal of World History 21/3 (Sep 2010): 471-495.

Gillick, Jon, Kevin Tang, and Robert M. Keller. "Machine Learning of Jazz Grammars.” Computer Music Journal 34/3 (Fall 2010): 56-66.

Givan, Benjamin. "Swing Improvisation: A Schenkerian Perspective." Theory E Practice 35 (2010): 25-56.

Givan, Benjamin. “Thelonious Monk's Pianism.” Journal of Musicology 26/3 (Summer 2009): 404-442.

Gridley, Mark C. and Hoff, Robert. "Are Music Perceptions Biased by Priming Effects of Journalism?” Psychology Journal 7/2 (2010): 55-60.

Gridley, Mark C. "Perception of Emotion in Jazz Improvisation." Advances in Psychology Research 62 (2010): 163-184.

Gridley, Mark C. “Trait Anger and Music Perception.” Creativity Research Journal 21 (2009): 134-137.

Gridley, Mark C. and Hoff, Robert. “Who’s Actually Angry, John Coltrane or His Critics?” Psychology Journal 4/4 (2007): 153-160.

Helgert, Lars. "Songs from Leonard Bernstein's Stage Works as Jazz Repertoire." American Music 27/3 (Fall 2009): 356-368. 
Hickey, Maud. "Can Improvisation be 'Taught'?: A Call for Free Improvisation in our Schools." International Journal of Music Education 27/4 (November 2009): 285299.

Iglesias, Iván. “(Re)construyendo la identidad musical española: el jazz y el discurso cultural del franquismo durante la Segunda Guerra Mundial / (Re)Constructing the Spanish Musical Identity: Jazz and the Cultural Discourses of Francoism during the Second World War." [Article written in Spanish.] Historia Actual Online $23 \quad$ (2010). http://www.historiaactual.org/Publicaciones/index.php/haol/article/view/503

Iseminger, Gary. "Sonicism and Jazz Improvisation." Journal of Aesthetics and Art Criticism 68/3 (2010): 297-299.

Kastin, David. "Fred $\mathrm{Ho}$ and the Evolution of Afro-Asian New American Multicultural Music.” Popular Music and Society 33/1 (2010): 1-8.

Keightley, Keir. "Taking Popular Music (and Tin Pan Alley and Jazz) Seriously.” Journal of Popular Music Studies 22/1 (2010): 90-97.

Kerr, Derrin, and Bruce Allen Knight. "Exploring an Industry-Based Jazz Education Performance Training Programme." International Journal of Music Education 28/4 (Nov 2010): 301-312.

Kingscott, John and Durrant, Colin. "Keyboard Improvisation: A Phenomenological Study." International Journal of Music Education 28/2 (May 2010): 127-144.

Klemp, Nathaniel, Ray McDermott, Jason Raley, Matthew Thibeault, Kimberly Powell, and Daniel Levitin. "Plans, Takes, and Mis-takes." Outlines. Critical Practice Studies 10/1 (2008). http://ojs.statsbiblioteket.dk/index.php/outlines/article/view/1964

Krnić, Rašeljka. "Džez Izme u popularne glazbe I elitne umjetnosti / Jazz between Popular and High Art." [Article written in Croatian.] Drustvena Istranzivanja 19/6 (Nov-Dec 2010): 1115-1138.

Laver, Mark T. “The Greatest Jazz Concert Ever': Pierre Bourdieu and the Shifting Ontology of Bebop." Critical Studies in Improvisation / Études critiques en improvisation 5/1 (Jan 2009).

http://www.criticalimprov.com/article/view/972/1625

Lehmann, Andreas C. and Reinhard Kopiez. "The Difficulty of Discerning Between Composed and Improvised Music.” Musicae Scientiae (Special Issue 2010): 113129. 
Le Menestrel, Sara and Jacques Henry. “'Sing Us Back Home': Music, Place, and the Production of Locality in Post-Katrina New Orleans.” Popular Music and Society 33/2 (2010): 179-202.

Lempert, Benjamin R. "Harryette Mullen and the Cotemporary Jazz Voice." Callaloo 33/4 (Fall 2010): 1059-1078.

Love, Stefan. “A Model of Common-Tone Connections Among Jazz Scales.” Journal of Music Theory Pedagogy 23 (2009): 155-169.

Lubet, Alex. "(Paralyzed on One) Sideman: Disability Studies Meets Jazz, through the Hands of Horace Parlan." Critical Studies in Improvisation / Études critiques en improvisation 6/2 (Dec 2010).

http://www.criticalimprov.com/article/view/1268/1916

Lundahl, Mats. "Adjust the Volume According to the Demands of Management and have a Suitable Local Repertory: Bebo Valdes and the Latin Music and Jazz Scene in Stockholm / Ajustar el volumen de acuerdo con las exigencias de la dirección y tener un repertorio adecuado para el local: Bebo Valdés y el escenario de música latina y jazz en Estocolmo." [Article written in Spanish.] Itamar: Revista de investigación musical-Territorios para el arte 3 (2010): 23-45.

Macías, Anthony. "Detroit was Heavy': Modern Jazz, Bebop, and African American Expressive Culture.” Journal of African American History 95/1 (Winter 2010): 4470.

Maestre, Esteban, Rafael Kersten Ramírez, and Xavier Stefan Serra. "Expressive Concatenative Synthesis by Reusing Samples from Real Performance Recordings.” Computer Music Journal 33/4 (Winter 2009): 23-42.

Marlow, Eugene. "Is the Laptop a Musical Instrument? Or, What's Old is New Again and Vice Versa." ETC: A Review of General Semantics 66/3 (Jul 2009): 341-344.

McLeod, Katherine. "Oui, Let's Scat': Listening to Multi-Vocality in George Elliott Clarke's Jazz Opera Quebecite.” Mosaic - A Journal for the Interdisciplinary Study of Literature 42/1 (Mar 2009): 133-150.

Nowakowski, Konrad. “'30 Negroes (Ladies and Gentlemen)': The Syncopated Orchestra in Vienna." Black Music Research Journal 29/2 (Fall 2009): 229-281.

Pearl, Phillip L. "Neurological Problems of Jazz Legends." Journal of Child Neurology 24/8 (Aug 2009): 1037-1042.

Philips, Damon J. and Young-Kyu Kim. "Why Pseudonyms? Deception as Identity Preservation Among Jazz Record Companies, 1920-1929.” Organization Science 20/3 (May-Jun 2009): 481-499. 
Piekut, Benjamin. "New Thing? Gender and Sexuality in the Jazz Composers Guild.” American Quarterly 62/1 (Mar 2010): 25-48.

Pinheiro, Diogo L. and Timoty J. Dowd. "All that Jazz: The Success of Jazz Musicians in Three Metropolitan Areas." Poetics 37/5 (Special Issue Oct 2009): 490-506.

Porter, Eric. “Jazz and Revival.” American Quarterly 61/3 (Sep 2009): 593-613.

Prouty, Kenneth E. “Toward Jazz's 'Official' History: The Debates and Discourses of Jazz History Textbooks.” Journal of Music History Pedagogy 1/1 (2010): 19-43. http://theams.us/ams-net/ojs/index.php/jmhp/article/view/4/26

Ramirez, Rafael, Esteban Maestre, and Xavier Serra. "Automatic Performer Identification in Commercial Monophonic Jazz Performances." Pattern Recognition Letters 31/12 (Special Issue Sep 2010): 1514-1523.

Ramshaw, Sara L. "The Creative Life of Law: Improvisation, Between Tradition and Suspicion.” Critical Studies in Improvisation / Etudes critiques en improvisation 6/1 (Jan 2010). http://www.criticalimprov.com/article/view/1084

Roberts, Matana. "Keeping On...” Critical Studies in Improvisation / Études critiques en improvisation 6/2 (Dec 2010). http://www.criticalimprov.com/article/view/1306/1907

Roueff, Olivier. "The Rise of the Middle: Domestication of Taste and Training of the Field of Jazz in France, 1941-1960 / La montée des intermediaries: Domestication du goût et formation du champ du jazz en France, 1941-1960.” [Article written in French.] Actes de la recherche en sciences sociales 181-182/1 (Mar 2010): 34-59.

Rye, Howard. "The Southern Syncopated Orchestra." Black Music Research Journal 29/2 (Fall 2009): 153-228.

Saayman, Melville and Riaan Rossouw. "The Cape Town International Jazz Festival: More Than Just Jazz.” Development Southern Africa 27/2 (2010): 255-272.

Sakakeeny, Matt. "Under the Bridge: An Orientation to Soundscapes in New Orleans." Ethnomusicology: Journal of the Society for Ethnomusicology 54/1 (Winter 2010): 1-27.

Salley, Keith. "Beyond Chord-Scale Theory: Realizing a Species Approach to Jazz Improvisation.” Journal of Music Theory Pedagogy 21 (2007): 101-122.

Seddon, Frederick and Michele Biasutti. "A Comparison of Modes of Communication Between Members of a String Quartet and a Jazz Sextet." Psychology of Music 37/4 (Oct 2009): 395-415. 
Smith, Derek T. "Development and Validation of a Rating Scale for Wind Jazz Improvisation Performance." Journal of Research in Music Education 57/3 (Oct 2009): 217-235.

Spry, Tami. "Call it Swing: A Jazz Blues Autoethnography." Cultural Studies/Critical Methodologies 10/4 (Aug 2010): 271-282.

Stanfield, Peter. "Crossover: Sam Katzman's Switchblade Calypso Bop Reefer Madness Swamp Girl or 'Bad Jazz', Calypso, Beatniks and Rock 'n' Roll in 1950s Teenpix.” Popular Music 29/3 (Oct 2010): 437-55.

Steinbeck, Paul. "Celebrating a Jazz Hero: A Symposium on the Role of Fred Anderson in Chicago's Jazz Legacy." Critical Studies in Improvisation / Études critiques en improvisation 6/2 (Dec 2010). http://www.criticalimprov.com/article/view/1019/1858

Steinbeck, Paul. "Patience, Sincerity, and Consistency': Fred Anderson's Musical and Social Practices." Critical Studies in Improvisation / Études critiques en improvisation 6/2 (Dec 2010). http://www.criticalimprov.com/article/view/1020/1860

Stevens, Timothy. "Early Ensembles and Recordings of John Grant Sangster." Context: A Journal of Music Research 34 (2009): 35-42.

Stras, Laurie. "Sing a Song of Difference: Connie Boswell and a Discourse of Disability in Jazz." Popular Music 28/3 (Oct 2009): 297-322.

Taylor, Jeffrey. "Brooklyn Rediscovers Cal Massey." American Music Review 39/2 (Spring 2010): 1-14.

Thompson, Michael J. "Theodore W. Adorno Defended against His Critics, and Admirers: A Defense of the Critique of Jazz." International Review of the Aesthetics and Sociology of Music 41/1 (Jun 2010): 37-49.

Wall, Tim and Andrew Dubber. "Experimenting with Fandom, Live Music, and the Internet: Applying Insights from Music Fan Culture to New Media Production.” Journal of New Music Research 39/2 (2010): 159-169.

Waters, Keith J., and J. Kent Williams. "Modeling Diatonic, Acoustic, Hexatonic, and Octatonic Harmonies and Progressions in Two- and Three-Dimensional Pitch Spaces; or Jazz Harmony after 1960.” Music Theory Online Volume 16/3 (Aug 2010).

http://www.mtosmt.org/issues/mto.10.16.3/mto.10.16.3.waters_williams.html

Watson, Kevin E. "Charting Future Directions for Research in Jazz Pedagogy: Implications of the Literature.” Music Education Research 12/4 (2010): 383-393. 
Watson, Kevin E. "The Effects of Aural Versus Notated Instructional Materials on Achievement and Self-Efficacy in Jazz Improvisation." Journal of Research in Music Education 58/3 (Oct 2010): 240-59.

Weinstein, Brian and Gridley, Mark C. "Visual Perception of Music." Psychology Journal 7/3 (2010): 80-87.

Wenceslas Lizé. "Le goût jazzistique en son champ: L'espace parisien de la jazzophilie / Jazz Tastes in its own Field: The Parisian Space of the Jazzophile." [Article written in French.] Actes de la recherche en sciences sociales 181-182/1(Mar 2010): 60-87.

Wilf, Eitan. "Swinging Within the Iron Cage: Modernity, Creativity, and Embodied Practice in American Postsecondary Jazz Education." American Ethnologist 37/3 (Aug 2010): 563-582.

Williams, Justin A. "The Construction of Jazz Rap as High Art in Hip-Hop Music." Journal of Musicology 27/4 (Fall 2010): 435-459.

Zagalaz, Juan C. "La metamorfosis de la música popular americana: el estilo de Teddy Wilson: 1935-1940 / The Metamorphosis of American Popular Music: the style of Teddy Wilson: 1935-1940." [Article written in Spanish.] Ensayos, Revista de la Facultad de Educación de Albacete 25 (2010). http://www.uclm.es/ab/educacion/ensayos/ensayos25/25_9.asp

Zhang, Xiaolu. "John Coltrane's Language of Contemporary Jazz Music: The System of Equal Thirds Cycles." [Article written in Chinese.] Yinyue yishu: Shanghai Yinyue Xueyuan xuebao / Art of music: Journal of the Shanghai Conservatory of Music 116/1 (2009): 22-32.

\section{ABOUT THE CONTRIBUTOR}

ROBIN DESMEULES completed a master's degree at Carleton University in Ottawa, Ontario. Her thesis explored issues in jazz and gender in Toronto. Originally from Sudbury, Ontario, Robin holds a BA with a combined specialization in music and political science from Laurentian University. She also trained at Humber College as a jazz saxophonist. She will begin a Masters in Library and Information Science at McGill University this September. 